\title{
Kecerdasan Emosional Anak Sekolah Dasar Saat Pembelajaran Daring
}

\section{Silviana Widuri Handayani ${ }^{*}$, Siti Masfuah ${ }^{2}$, Much. Arsyad Fardani ${ }^{3}$}

1,2 Pendidikan Guru Sekolah Dasar, Universitas Muria Kudus, Kudus, Indonesia

\section{A R T I C L E I N F O \\ Article history \\ Received July 14, 2021 \\ Revised July 17, 2021 \\ Accepted September 30, 2021 \\ Available online October 25, 2021}

Kata Kunci:

Kecerdasan Emosional, Daring, Sekolah Dasar

Keywords:

Emotional Intelligence, Online, Elementary School

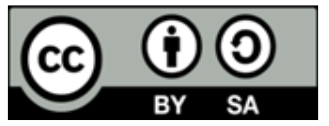

This is an open access article under the CC BY-SA license.

Copyright $@ 2021$ by Author. Published by Universitas Pendidikan Ganesha.

\begin{abstract}
A B S T R A K
Pandemi covid 19 telah membawa dampak yang beragam salah satunya terjadinya perubahan proses pembelajaran disekolah menjadi pembelajaran daring. Hal ini menyebabkan rendahnya minat serta motivasi siswa untuk belajar yang dipengaruhi oleh factor emosional yang tidak stabil. Penelitian ini bertujuan mendeskripsikan potret kecerdasan emosional anak saat pembelajaran daring siswa. Subjek penelitian ini adalah 6 siswa dengan kategori 2 siswa dengan prestasi belajar tinggi, 2 siswa dengan prestasi belajar rata-rata dan 2 siswa dengan prestasi belajar rendah. Instrumen yang digunakan dalam mengumpulkan data adalah observasi dan wawancara kepada siswa, guru dan orang tua siswa untuk menganalisis potret kecerdasan emosional siswa. Analisis data yang digunakan meliputi reduksi data, penyajian data dan verifikasi. Berdasarkan analisis data kualitatif diperoleh hasil bahwa terdapat 2 siswa dengan prestasi belajar tingi, memiliki kecerdasan emosional sangat tinggi karena mampu mecapai 5 indikator dengan baik. 1 siswa laki-laki dengan prestasi belajar rata-rata memiliki kecerdasan emosional tinggi dengan mencapai 4 indikator dengan baik. 1 siswa perempuan dengan prestasi belajar rata-rata memiliki kecerdasan emosional rata-rata karena mencapai 3 indikator dengan baik. 1 siswa laki-laki dengan inisial dengan prestasi belajar rendah memiliki kecerdasan emosional rendah karena mencapai 2 indikator dengan baik dan 1 siswa perempuan dengan prestasi belajar memiliki kecerdasan emosional sangat rendah karena hanya mampu mencapai 1 indikator dengan baik.
\end{abstract}

\section{A BS TRACT}

The COVID-19 pandemic has brought various impacts, one of which is the change in the learning process in schools to online learning. It causes students' low interest and motivation to learn, influenced by unstable emotional factors. This study describes the portrait of children's emotional intelligence during online student learning. The subjects of this research were six students with category two students with high learning achievement, two students with average learning achievement and two students with low learning achievement. The instruments used in collecting data were observations and interviews with students, teachers and parents of students to analyze the portrait of students' emotional intelligence. The data analysis used includes data reduction, data presentation and verification. Based on the analysis of qualitative data, the results showed that two students with high learning achievement had very high emotional intelligence because they were able to achieve five indicators well. One male student with average learning achievement has high emotional intelligence by achieving four indicators well. One female student with average academic achievement had average emotional intelligence because she achieved three indicators well. One male student with initials with low learning achievement has low emotional intelligence because it achieves two indicators well, and one female student with learning achievement has faulty emotional intelligence because it can only achieve one indicator well.

\section{PENDAHULUAN}

Pendidikan merupakan salah suatu proses yang diperlukan untuk mendapatkan keseimbangan dan kesempurnaan dalam perkembangan individu maupun masyarakat. Pendidikan adalah suatu proses dalam rangka mempengaruhi peserta didik supaya mampu menyesuaikan diri sebaik mungkin dengan 
lingkungannya, dan akan menimbulkan perubahan dalam dirinya yang memungkinkannya untuk berfungsi secara kuat dalam kehidupan masyarakat (Kencanawati et al., 2020; Suhendro, 2020). Pada dasarnnya pendidikan bermaksud membantu siswa untuk mengembangkan seluruh potensi yang dimilikinya (Suryana, 2020; Wulandari et al., 2020). Untuk mencapai tujuan pendidikan maka proses pembelajaran harus dilakukan dengan baik dan efektif. Dengan melaksanakan pembelajaran yang mampu memberikan siswa suatu pengalaman menerima, mendengar, dan melihat apa yang disampaikan oleh guru (Anggriani et al., 2020; Pratiwi et al., 2018; Sairo et al., 2019) . Namun saat ini dunia sedang dilanda wabah virus covid-19 (R. S. Putri \& Purwanto, 2020; Susilo et al., 2020). Dalam menekan semakin meluasanya wabah covid-19, di bidang pendidikan pemerintah mengeluarkan kebijakan melalui Kementerian Pendidikan dan Kebudayaan (Kemendikbud) merespon dengan kebijakan belajar dari rumah melalui pembelajaran daring selama periode karantina wilayah atau lockdown di Indonesia (Anugrahana, 2020; Putria et al., 2020).

Pembelajaran daring merupakan sebuah inovasi pendidikan yang memanfaatkan internet dan teknologi dalam proses pembelajarannya (Lapitan et al., 2021; Maison et al., 2021; Saputra et al., 2021). Pembelajaran daring dilaksnakan dengan. Pembelajaran daring dilaksanakan dengan memanfaatkan berbagai aplikasi, seperti: zoom, google classroom, whatsapp, dan aplikasi lainnya sehingga tetap terjadi interaksi antara siswa dan guru (Binali et al., 2021; Fauzia et al., 2021; Maqableh \& Alia, 2021). Pembelajaran daring menyediakan akses belajar bagi semua orang, sehingga menghapus hambatan seperti jarak dan kendala tatap muka (Nambiar, 2020; Saha et al., 2021; Selvaraj et al., 2021). Pembelajaran daring memudahkan siswa untuk belajar kapan dan dimana saja, selain itu dengan belajar daring siswa akan terlatih untuk belajar mandiri dengan mencari imlu melalui media internet, youtube dll (Hwang et al., 2020; Kkese, 2020; Lage-Cala et al., 2020). Dengan kemudahan belajar, kebebasan waktu diharapkan pembelajaran daring mampu meningkatkan hasil belajar siswa pada masa pandemic ini. Namun yang tejadi dilapangan pembelajarn daring tidak hanya membawa dampak positif.

Berdasarkan hasil analisis kebutuhan yang dilakukan pada siswa kelas V SD N Jatiroto 02, pembelajaran dikatakan tidak berjalan secara maksimal. Hasil observasi menunjukkan bahwa masih banyak siswa yang kurang mengerti bagaimana cara untuk mengerjakan atau menyelesaikan tugas yang diberikan guru, banyak anak yang tidak maksimal dalam mengikuti pembelajaran daring, banyak siswa yang mudah menyerah dan kurang bersemangat dalam mengikuti pembelajaran. Materi pembelajaran dan tugas-tugas sekolah yang diberikan oleh guru di unggah melalui aplikasi sosial media berupa WhatsApp. Ini membuat anak lebih sering menggunakan hp untuk belajar. Namun sebagian siswa mengaku lebih menyukai bermain hp untuk bermain dari pada untuk mengerjakan tugas sekolah. Adanya game online, dan media online yang lain membuat siswa menjadi candu dalam bermain game dan media online, mengakibatkan pembelajaran yang berjalan tidak efektif (Liu et al., 2020; Rahmawati \& Latifah, 2020; Samaha \& Hawi, 2016). Pernyataan tersebut menjadi lebih kuat dengan penjelasan yang diberikan oleh guru bahwa ada beberapa siswa yang terlambat mengerjakan tugas yang diberikan oleh guru. Penugasan diberikan melalui aplikasi group pada WhatsApp membuat proses tanya jawab yang mungkin sulit dilakukan karena permasalahan jaringan dan orang tua yang memiliki pendidikan, pekerjaan dan ekonomi yang berbeda sehingga siswa cenderung memiliki tingkat emosi yang beragam. Dalam proses belajar akan sangat dipengaruhi oleh kecerdasan emosional siswa, jika siswa dapat mengendalikan dirinya maka ia tidak akan terganggu dengan lingkungan sekitarnya dan akan membuat siswa lebih berkonsentrasi pada proses belajar (Priadi, 2018; Rambe et al., 2018; Setiadi, 2018). Dalam hal ini yang terpenting adalah bagaimana siswa dapat mengolah kemapuan yang ada dalam dirinya.

Kemampuan siswa tersebut tercermin dalam segenap kecerdasan emosi yang dimilikinya. Kecerdasan emosional adalah kombinasi dari kemampuan menyadari, memahami, mengontrol diri sehingga dapat menggunakan pengetahuannya untuk mencapai keberhasilan (Nurdiansyah, 2016; Sairo et al., 2019). Dengan begitu kecerdasan emosional yang tinggi dapat membuat siswa mencapai keberhasilannya dalam belajar. Kecerdasan emosional adalah kemampuan sesorang untuk mengenali perasaanya sendiri dan orang lain, kemampuan untuk mengendalikan diri, kemampuan untuk memotivasi diri sendiri dalam menghadapi frustasi dan kesanggupan dalam mengendalikan dorongan hati dan emosi (Akimas, 2016; Y. S. Putri, 2016; Said \& Rahmawati, 2018). Kecerdasan emosional pada siswa dapat diukur melalui beberapa indikator, yaitu: pertama, Perceiving emotion adalah kemampuan untuk mengelola emosinya dan orang lain, dan juga yang berkenaan dengan benda, seni, sejarah, musik, dan situli yang lain. Kedua, Using emotion to falitate thought adalah kemampuan untuk mebangkitkan, menggunakan, dan merasakan emosi sebagai kebutuhan untuk mengkomunikasikan perasaan, atau menggunakannya dalam proses kognitif yang lainnya. Ketiga, Understanding emotion, adalah kemampuan untuk memahami informasi emosional, dan mengapresiasi makna emosi diri. Keempat, Managing emotion, adalah kemampuan untuk menjadi terbuka terhadap perasaan, untuk mengatur emosi diri sendiri dan orang lain untuk mendorong permahaman dan pertumbuhan personal. Lima indikator kecerdasan 
emosional yang dapat menjadi pedoman bagi individu untuk mencapai kesuksesan, yaitu: kesadaran diri, mengelola emosi, memanfaatkan emosi, membaca emosi orang lain dan membina hubungan, yaitu merupakan keterampilan mengelola emosi orang lain, mempertahankan hubungan dengan orang lain melalui keterampilan sosial, kepemimpinan dan keberhasilan hubungan antar pribadi (Goleman, 2015; Prafitriani et al., 2019; Satriyono \& Vitasmoro, 2018).

Kecerdasan emosional juga dapat mendukung kesuksesan siswa dalam belajar, sehingga faktor kecerdasan emosional memiliki peran penting dalam pembelajaran (Dharmawan, 2013; Rachmiati, 2016; Setyawan \& Simbolon, 2018). Seorang siswa dengan kecerdasan emosional tinggi, dapat ditandai dari perilaku yang ditunjukkan, seperti mampu mengenali dan mengelola emosi yang muncul dari dalam dirinya, mampu memotivasi dirinya untuk belajar, mampu berempati kepada orang lain, dan dapat membangun hubungan yang baik bersama orang lain (Nurfitriyanti, 2017; Supriyanto, 2021; Yaya Setiadi, 2018). Peserta didik diharapkan mampu untuk mengelola emosi dalam dirinya dengan pengelolaan emosi yang baik serta selalu berfikir positif (Arieska et al., 2018; Mirnawati \& Basri, 2018; Munirah \& Ahmad Putri, 2018). Siswa yang memiliki kecerdasan emosional yang baik mampu mengatasi tantangan dalam pembelajaran daring, karena kecerdasan emosional berkenaan dengan kemampuan siswa dalam mengelola dirinya agar dapat belajar secara mandiri di rumah, mampu memotivasi dirinya agar selalu semangat. Hal ini sejalan dengan penelitian sebelumnya yang menunjukkan bahwa kecerdasan emosional berpengaruh terhadap prestasi belajar peserta didik (Astuti et al., 2019; Maghfiroh \& Putri Mahanani, 2021). Peserta didik yang memilki kecerdasan emosional yang baik akan mampu meningkatkan kemampuan berfikir kritisnya (Costa et al., 2021; Gunarsih, 2016).

Temuan penelitian sebelumnya juga menunjukkan bahwa kecerdasan emosional yang dimiliki oleh peserta didik berpengaruh terhadap prestasi yang dimilkinya (Ratnadi, 2017; Risma, 2012; Sairo et al., 2019). Perbedaan penelitian ini dengan penelitian terdahulu adalah penelitian ini hanya mendeskripsikan tingkat kecerdasan emosional dengan prestasi belajar siswa, sedangkan penelitian terdahulu lebih banyak yang diteliti yaitu kontribusi motivasi belajar, kecerdasan emosional dan kecerdasan intelektual terhadap prestasi belajar. Penelitian ini bertujuan untuk mendeskripsikan potret kecerdasan emosional anak saat pembelajaran daring siswa kelas V SD N Jatiroto 02. Dengan kecerdasan emosional yang baik selama pembelajaran daring diharapkan peserta didik mampu belajar dengan baik sehingga mampu meningkatkan hasil belajarnya.

\section{METODE}

Jenis penelitian ini adalah penelitian deskriptif kualitatif. Penelitian ini berupaya mendeskripsikan potret kecerdasan emosional anak saat pembelajaran daring. Pelaksanaan penelitian kualitatif ini dilaksanakan pada siswa kelas V SD N Jatiroto 02 dengan seubjek penelitian 6 siswa (3 siswa laki-laki dan 3 siswa perempuan) dengan kategori 2 siswa dengan prestasi belajar tinggi, 2 siswa dengan prestasi belajar rata-rata dan 2 siswa dengan prestasi belajar rendah. Penelitian kualitatif ini dilakukan dengan pengumpulan data yang peneliti dapatkan melalui kegiatan observasi dan wawancara dengan analisis data yang digunakan meliputi reduksi data, penyajian data dan verifikasi (Sugiyono, 2016). Dalam mengetahui kecerdasan emosional pada siswa dapat diukur melalui kecakapan indikatornya. Dalam mengukur tingkat kecerdasan emosional siswa digunakan tingkat kecerdasan emosional dengan kategori tingkat kecerdasan emosional yang sama yakni kategori sangat tinggi jika anak mampu mencapai 5 indikator kecerdasan emosional dengan baik, kategori tinggi jika anak mampu mencapai 4 indikator kecerdasan emosional dengan baik, sedang mampu mencapai 3 indikator kecerdasan emosional dengan baik, rendah mampu mencapai 2 indikator kecerdasan emosional dengan baik, dan sangat rendah mampu mencapai 1 indikator kecerdasan emosional dengan baik (Nurdiansyah, 2016).

\section{HASIL DAN PEMBAHASAN}

Hasil

Penelitian ini bertujuan mendeskripsikan potret kecerdasan emosional anak saat pembelajaran daring siswa kelas V SD N Jatiroto 02. Penelitian ini didukung dengan hasil penelitian yang pernah dilakukan terdahulu menyatakan bahwa adanya hubungan yang signifikan antara kecerdasan emosional dan prestasi belajar (Fauziah, 2015). Penelitian ini diawali dengan studi pendahuluan dilakukan dengan cara wawancara kepada guru kelas 5 mengenai proses pembelajaran daring selama pandemi COVID-19 dan untuk mendapatkan data anak yang berkaitan dengan kriteria anak dengan prestasi belajar tinggi, anak dengan prestasi belajar rata-rata, anak dengan prestasi belajar rendah. Berdasarkan hasil studi pendahuluan didapatkan hasil bahwa 2 anak dengan prestasi belajar tinggi dengan inisial ZSL dan RMR sangat baik dalam mengikuti pembelajaran, tidak banyak masalah di sekolah, tidak pernah bertengkar 
atau mengganggu temannya dan selalu tepat waktu dalam mengumpulkan tugas. 2 anak dengan prestasi belajar rata-rata dengan inisial RMP dan SNW cukup baik dalam mengikuti pembelajaran namun terkadang jika mereka sudah mulai bosan dengan pembelajaran mereka mengalihkannya dengan bercanda atau berbicara dengan teman dan bermain. 2 anak dengan prestasi belajar rendah dengan inisial SJRP dan RDF tidak antusias dalam mengikuti pembelajaran, cukup bermasalah di sekolah dan sering membuat rusuh atau gaduh dengan banyak berbicara dan kerap bertengkar dengan temannya. Tahap selanjutnya Tahap selanjutnya adalah wawancara pada anak yang telah terpilih sesuai dengan kategori yang akan diteliti yaitu anak yang memiliki prestasi belajar tinggi, atau biasanya mendapat rangking 1 dan 2 dikelas. Anak dengan prestasi belajar rata-rata yaitu anak dengan nilai rata-rata pada umumnya. Anak dengan prestasi belajar rendah. Wawawancara mendalam dalam penelitian ini digunakan untuk mengukur tingkat kecerdasan emosional siswa. Kecerdasan emosional pada siswa dapat diukur menggunakan indicator yaitu kesadaran diri, indicator mengelola emosi, indikator memanfaatkan emosi secara produktif, indikator empati (membaca emosi), indikator membina hubungan (Goleman, 2015).

Berikut adalah uraian hasil observasi dan wawancara dari siswa, guru dan orang tua siswa. Inisial ZSL dengan pretasi belajar tinggi Indikator (1) kesadaran diri, ZSL pada saat pembelajaran daring berlangsung ketika ia kurang faham dengan materi dan tugas dari gurunya, ia mula mula bertanya pada temannya, pada saat temannya tidak bisa ia mulai bertanya kepada orang tuanya dan jika orang tuanya juga tidak faham baru akan bertanya kepada gurunya. Hal ini membuktikan bahwa ia memiliki kesadaran diri yang tinggi dimana saat ia tidak mampu mengerjakan tugasnya ia mengenali perasaanya dengan tidakan untuk bertanya kepada orang tua maupun gurunya. Indikator (2) mengelola emosi, ZSL saat mengikuti pembelajaran daring ia tidak terganggu dengan keadaan lingkungannya walaupun saat temantemannya sedang bercanda ia tetap fokus untuk mengerjakan tugasnya dan sesekali meberi pengertian kepada temannya untuk mengikuti pembelajaran daring dengan baik agar teman-temannya faham dengan materi dan tugas yang diberikan oleh guru. Hal ini membuktikan bahwa mereka dapat mengelola emosi diri dengan sangat baik karena memiliki toleransi tinggi dan tidak menimbulkan perkelahian pada temantemannya. Indikator (3) memanfaatkan emosi, ia dapat mengikuti pembelajaran daring dengan baik, dan tertib dalam mengerjakan tugasnya. Mereka sangat fokus tidak kebingungan dalam mengerjakan tugasnya. Hal ini membuktikan bahwa mereka dapat memanfaatkan emosi dengan sangat baik karena dapat memusatkan perhatian pada tugas yang mereka kerjakan dan dapat bertanggung jawab dengan apa yang tengah ia kerjakan. Indikator (4) empati (membaca emosi) dalam membaca emosi orang lain ia memiliki empati atau kepekaan yang tinggi terhadap orang lain hal ini dibuktikan saat temannya sedang merasa sedih dan tidak ingin mengikuti pembelajaran daring ia memberi semangat dan mengajak belajar bersama agar tetap semangat belajar. indikator (5) membina hubungan, ZSL dapat membina hubungan dengan baik karena ia selalu menyapa atau berjabat tangan dengan temannya ketika bertemu, senang berkunjung ke rumah temannya untuk mengerjakan tugas bersama dan lebih baik dalam menyelesaikan pertikaian dengan temannya karena ketika ia merasa bersalah ia pun mengakuinya dan meminta maaf. Dan berdasarkan hasil wawancara dengan guru ZSL adalah anak yang memiliki prestasi belajar tinggi dan tidak banyak masalah di sekolah, tidak pernah bertengkar atau mengganggu temannya dan selalu tepat waktu dalam mengumpulkan tugas. Menurut orang tua ZSL saat berada di rumah ZSL adalah anak yang baik selalu menuruti perkataan orang tuanya, rajin belajar dan tidak mudah marah saat ditegur orang tuanya. Dengan begitu ZSL dapat mencapai 5 indikator kecerdasan emosional dengan baik.

Inisial RMR dengan hasil belajar tinggi, Indikator (1) kesadaran diri, RMR pada saat pembelajaran daring berlangsung ketika ia kurang faham dengan materi dan tugas dari gurunya, ia mula mula bertanya pada temannya, pada saat temannya tidak bisa ia mulai bertanya kepada orang tuanya dan jika orang tuanya juga tidak faham baru akan bertanya kepada gurunya. Hal ini membuktikan bahwa ia memiliki kesadaran diri yang tinggi dimana saat ia tidak mampu mengerjakan tugasnya ia mengenali perasaanya dengan tidakan untuk bertanya kepada orang tua maupun gurunya. Indikator (2) mengelola emosi, RMR saat mengikuti pembelajaran daring ia tidak terganggu dengan keadaan lingkungannya walaupun saat teman-temannya sedang bercanda ia tetap fokus untuk mengerjakan tugasnya dan sesekali meberi pengertian kepada temannya untuk mengikuti pembelajaran daring dengan baik agar teman-temannya faham dengan materi dan tugas yang diberikan oleh guru. Hal ini membuktikan bahwa mereka dapat mengelola emosi diri dengan sangat baik karena memiliki toleransi tinggi dan tidak menimbulkan perkelahian pada teman-temannya. Indikator (3) memanfaatkan emosi, ia dapat mengikuti pembelajaran daring dengan baik, dan tertib dalam mengerjakan tugasnya. Mereka sangat fokus tidak kebingungan dalam mengerjakan tugasnya. Hal ini membuktikan bahwa mereka dapat memanfaatkan emosi dengan sangat baik karena dapat memusatkan perhatian pada tugas yang mereka kerjakan dan dapat bertanggung jawab dengan apa yang tengah ia kerjakan. Indikator (4) empati (membaca emosi) dalam membaca emosi orang lain ia memiliki empati atau kepekaan yang tinggi terhadap orang lain hal ini dibuktikan saat temannya sedang merasa sedih dan tidak ingin mengikuti pembelajaran daring ia 
memberi semangat dan mengajak belajar bersama agar tetap semangat belajar. indikator (5) membina hubungan, RMR dapat membina hubungan dengan baik karena ia selalu menyapa atau berjabat tangan dengan temannya ketika bertemu, senang berkunjung ke rumah temannya untuk mengerjakan tugas bersama dan lebih baik dalam menyelesaikan pertikaian dengan temannya karena ketika ia merasa bersalah ia pun mengakuinya dan meminta maaf. Dan berdasarkan hasil wawancara dengan guru RMR adalah anak yang memiliki prestasi belajar tinggi dan tidak banyak masalah di sekolah, jarang sekali bertengkar atau mengganggu temannya dan selalu tepat waktu dalam mengumpulkan tugas. Menutut orang tua RMR saat dirumah RMR adalah anak yang baik, bertanggung jawab dengan apa yang tengah ia kerjakan baik dalam hal pekerjaan rumah membantu orang tua maupun dalam hal belajar, sangat baik dalam membina hubungan dengan orang tuanya karena RMR adalah anak yang penurut. Dengan begitu RMR dapat mencapai 5 indikator kecerdasan emosional dengan baik.

Inisial RMP siswa dengan prestasi belajar rata-rata, Indikator (1) kesadaran diri, RMP pada saat pembelajaran daring berlangsung ketika ia kurang faham dengan materi dan tugas dari gurunya, ia mulamula bertanya pada temannya, pada saat temannya tidak bisa ia mulai bertanya kepada orang tuanya dan jika orang tuanya juga tidak faham baru akan bertanya kepada gurunya. Hal ini membuktikan bahwa ia memiliki kesadaran diri yang tinggi dimana saat ia tidak mampu mengerjakan tugasnya ia mengenali perasaanya dengan tidakan untuk bertanya kepada orang tua maupun gurunya. Indikator (2) mengelola emosi, RMP saat mengikuti pembelajaran daring ia tidak terganggu dengan keadaan lingkungannya walaupun saat teman-temannya sedang bercanda ia tetap fokus untuk mengerjakan tugasnya dan sesekali meberi pengertian kepada temannya untuk mengikuti pembelajaran daring dengan baik agar temantemannya faham dengan materi dan tugas yang diberikan oleh guru. Hal ini membuktikan bahwa mereka dapat mengelola emosi diri dengan sangat baik karena memiliki toleransi tinggi dan tidak menimbulkan perkelahian pada teman-temannya. Indikator (3) memanfaatkan emosi, ia dapat mengikuti pembelajaran daring dengan baik, dan tertib dalam mengerjakan tugasnya. RMP sangat fokus tidak kebingungan dalam mengerjakan tugasnya. Hal ini membuktikan bahwa ia dapat memanfaatkan emosi dengan sangat baik karena dapat memusatkan perhatian pada tugas yang mereka kerjakan dan dapat bertanggung jawab dengan apa yang tengah ia kerjakan. Indikator (4) empati (membaca emosi) dalam membaca emosi orang lain ia memiliki empati atau kepekaan yang kuang terhadap orang lain hal ini dibuktikan saat temannya sedang merasa sedih dan tidak ingin mengikuti pembelajaran daring ia terlihat biasa saja dan tidak menunjukan perhatian dengan bertanya tentang masalah temannya atau memberi semangat dan mengajak belajar bersama agar tetap semangat belajar. Indikator (5) membina hubungan, RMP dapat membina hubungan dengan baik karena ia selalu menyapa atau berjabat tangan dengan temannya ketika bertemu, senang berkunjung ke rumah temannya untuk mengerjakan tugas bersama dan lebih baik dalam menyelesaikan pertikaian dengan temannya karena ketika ia merasa bersalah ia pun mengakuinya dan meminta maaf. Dan berdasarkan hasil wawancara dengan guru, RMP adalah anak yang memiliki prestasi belajar rata-rata dan tidak banyak masalah di sekolah, jarang sekali bertengkar atau mengganggu temannya dan selalu tepat waktu dalam mengumpulkan tugas namun kurang memiliki kepekaan dengan temannya. Menurut orang tua RMP saat dirumah RmP adalah anak yang baik, bertanggung jawab dengan apa yang tengah ia kerjakan baik dalam hal pekerjaan rumah membantu orang tua maupun dalam hal belajar, sangat baik dalam membina hubungan dengan orang tuanya karena RMP adalah anak yang penurut namun kurang memiliki empati dengan keluarganya karena saat orang tuanya menegurnya dia merasa terganggu. Dengan begitu RMP dapat mencapai 4 indikator kecerdasan emosional dengan baik, yaitu indikatoe (1) kesadaran diri, (2) mengelola emosi, (3) meanfaatkan emosi, (5) membina hubungan.

Inisial SNW adalah siswa dengan prestasi belajar rata-rata, Indikator (1) kesadaran diri, SNW pada saat pembelajaran daring berlangsung ketika ia kurang faham dengan materi dan tugas dari gurunya, ia bertanya pada temannya, orangtuanya maupun gurunya untuk menyelasaikan tugasnya. Hal ini membuktikan bahwa ia kuang dalam kesadaran diri dimana saat ia tidak mampu mengerjakan tugasnya ia tidak mampu mengenali perasaanya dengan tidakan untuk bertanya kepada orang tua maupun gurunya. Indikator (2) mengelola emosi, SNW saat mengikuti pembelajaran daring ia merasa terganggu dengan keadaan lingkungannya apalagi saat teman-temannya sedang bercanda ia kehilangan fokus untuk mengerjakan tugasnya ia pun marah dengan temannya karena iana menjadi tidak faham dengan materi dan tugas yang diberikan oleh guru. Hal ini membuktikan bahwa SNW tidak dapat mengelola emosi diri dengan baik karena tidak memiliki toleransi dan menimbulkan perkelahian pada teman-temannya. Indikator (3) memanfaatkan emosi, dalam mengikuti pembelajaran daring kurang tertib dan dalam mengerjakan tugasnya masih. kebingungan dan kurang fokus. Hal ini membuktikan bahwa SNW tidak memanfaatkan emosi dengan baik karena tidak dapat memusatkan perhatian pada tugas yang mereka kerjakan dan tidak bertanggung jawab dengan apa yang tengah ia kerjakan. Indikator (4) empati (membaca emosi) dalam membaca emosi orang lain ia memiliki empati atau kepekaan yang baik terhadap orang lain hal ini dibuktikan saat temannya sedang merasa sedih dan tidak ingin mengikuti pembelajaran 
daring ia terlihat menunjukan perhatian dengan bertanya tentang masalah temannya dan memberi semangat dan mengajak belajar bersama agar tetap semangat belajar. Indikator (5) membina hubungan, SNW dapat membina hubungan dengan baik karena ia selalu menyapa atau berjabat tangan dengan temannya ketika bertemu, senang berkunjung ke rumah temannya untuk mengerjakan tugas bersama dan lebih baik dalam menyelesaikan pertikaian dengan temannya karena ketika ia merasa bersalah ia pun mengakuinya dan meminta maaf. Dan berdasarkan hasil wawancara dengan guru, SNW adalah anak yang memiliki prestasi belajar rata-rata dan tidak terlalu bermasalah di sekolah, namun mudah marah dengan temannya saat berbeda pendapat, cukup tepat waktu dalam mengumpulkan tugas, dan memiliki kepekaan dengan temannya. Menurut orang tua SNW saat dirumah SNW adalah anak yang baik, namun mudah marah saat bertrngkar dengan adiknya, kurang bertanggung jawab dengan apa yang tengah ia kerjakan baik dalam hal pekerjaan rumah membantu orang tua maupun dalam hal belajar, sangat baik dalam membina hubungan dengan orang tuanya karena Snw adalah anak yang penurut namun kurang memiliki empati dengan keluarganya karena saat orang tuanya menegurnya dia merasa terganggu. Dengan begitu SNW dapat mencapai 3 indikator kecerdasan emosional dengan baik, yaitu indikator (1) kesadaran diri, indikator (4) empati dan indikator (5) membina hubungan .

Inisial SJRP adalah siswa dengan prestasi belajar rendah, Indikator (1) kesadaran diri, SJRP pada saat pembelajaran daring berlangsung ketika ia kurang faham dengan materi dan tugas dari gurunya, ia tidak mau bertanya pada temannya, orangtuanya maupun gurunya. Hal ini membuktikan bahwa ia kuang dalam kesadaran diri dimana saat ia tidak mampu mengerjakan tugasnya ia tidak mampu mengenali perasaanya dengan tidakan untuk bertanya kepada orang tua maupun gurunya. Indikator (2) mengelola emosi, SjRP saat mengikuti pembelajaran daring ia merasa terganggu dengan keadaan lingkungannya apalagi saat teman-temannya sedang bercanda ia kehilangan fokus untuk mengerjakan tugasnya ia pun marah dengan temannya karena iana menjadi tidak faham dengan materi dan tugas yang diberikan oleh guru. Hal ini membuktikan bahwa SJRP tidak dapat mengelola emosi diri dengan baik karena tidak memiliki toleransi dan menimbulkan perkelahian pada teman-temannya. Indikator (3) memanfaatkan emosi, dalam mengikuti pembelajaran daring kurang tertib dan dalam mengerjakan tugasnya masih . kebingungan dan kurang fokus. Hal ini membuktikan bahwa SJRP tidak memanfaatkan emosi dengan baik karena tidak dapat memusatkan perhatian pada tugas yang mereka kerjakan dan tidak bertanggung jawab dengan apa yang tengah ia kerjakan. Indikator (4) empati (membaca emosi) dalam membaca emosi orang lain ia memiliki empati atau kepekaan yang baik terhadap orang lain hal ini dibuktikan saat temannya sedang merasa sedih dan tidak ingin mengikuti pembelajaran daring ia terlihat menunjukan perhatian dengan bertanya tentang masalah temannya dan memberi semangat dan mengajak belajar bersama agar tetap semangat belajar. Indikator (5) membina hubungan, Rmr dapat membina hubungan dengan baik karena ia selalu menyapa atau berjabat tangan dengan temannya ketika bertemu, senang berkunjung ke rumah temannya untuk mengerjakan tugas bersama dan lebih baik dalam menyelesaikan pertikaian dengan temannya karena ketika ia merasa bersalah ia pun mengakuinya dan meminta maaf. Dan berdasarkan hasil wawancara dengan guru, Snw adalah anak yang memiliki prestasi belajar rata-rata dan tidak terlalu bermasalah di sekolah, namun mudah marah dengan temannya saat berbeda pendapat, cukup tepat waktu dalam mengumpulkan tugas, dan memiliki kepekaan dengan temannya. Menurut orang tua SJRP saat dirumah SJRP adalah anak yang baik, namun mudah marah saat bertrngkar dengan adiknya, kurang bertanggung jawab dengan apa yang tengah ia kerjakan baik dalam hal pekerjaan rumah membantu orang tua maupun dalam hal belajar, sangat baik dalam membina hubungan dengan orang tuanya karena SJRP adalah anak yang penurut namun kurang memiliki empati dengan keluarganya karena saat orang tuanya menegurnya dia merasa terganggu. Dengan begitu SJRP dapat mencapai 2 indikator kecerdasan emosional dengan baik, yaitu indikator (4) empati dan indikator (5) membina hubungan.

Inisial RDF adalah siswa dengan prestasi belajar rendah, Indikator (1) kesadaran diri, RDF pada saat pembelajaran daring berlangsung ketika ia kurang faham dengan materi dan tugas dari gurunya, ia tidak mau bertanya pada temannya, orangtuanya maupun gurunya. Hal ini membuktikan bahwa ia kuang dalam kesadaran diri dimana saat ia tidak mampu mengerjakan tugasnya ia tidak mampu mengenali perasaanya dengan tidakan untuk bertanya kepada orang tua maupun gurunya. Indikator (2) mengelola emosi, RDF saat mengikuti pembelajaran daring ia merasa terganggu dengan keadaan lingkungannya apalagi saat teman-temannya sedang bercanda ia kehilangan fokus untuk mengerjakan tugasnya ia pun marah dengan temannya karena iana menjadi tidak faham dengan materi dan tugas yang diberikan oleh guru. Hal ini membuktikan bahwa RDF tidak dapat mengelola emosi diri dengan baik karena tidak memiliki toleransi dan menimbulkan perkelahian pada teman-temannya. Indikator (3) memanfaatkan emosi, dalam mengikuti pembelajaran daring kurang tertib dan dalam mengerjakan tugasnya masih . kebingungan dan kurang fokus. Hal ini membuktikan bahwa RDF tidak memanfaatkan emosi dengan baik karena tidak dapat memusatkan perhatian pada tugas yang mereka kerjakan dan tidak bertanggung jawab dengan apa yang tengah ia kerjakan. Indikator (4) empati (membaca emosi) RDF kurang baik dalam 
membaca emosi hal ini dikarenakan RDF tidak mau menerima sudut pandang orang lain dan kerap bertengkar dengan temannya saat berbeda pendapat. Indikator (5) membina hubungan, RDF dapat membina hubungan dengan baik karena ia selalu menyapa atau berjabat tangan dengan temannya ketika bertemu, senang berkunjung ke rumah temannya untuk mengerjakan tugas bersama. Dan berdasarkan hasil wawancara dengan guru, RDF adalah anak yang memiliki prestasi belajar rata-rata dan cukup bermasalah di sekolah, mudah marah dengan temannya saat berbeda pendapat, tidak tepat waktu dalam mengumpulkan tugas, dan memiliki tidak kepekaan dengan temannya. Menurut orang tua RDF saat dirumah RDF adalah anak yang baik, namun mudah marah, kurang bertanggung jawab dengan apa yang tengah ia kerjakan baik dalam hal pekerjaan rumah membantu orang tua maupun dalam hal belajar, sangat baik dalam membina hubungan dengan orang tuanya karena RDF adalah anak yang penurut namun kurang memiliki empati dengan keluarganya karena saat orang tuanya menegurnya dia merasa terganggu. Dengan begitu RDF dapat hanya mencapai 1 indikator kecerdasan emosional dengan baik, yaitu indikator ke 5 membina hubungan. Hasil capaian indikator masing-masing siswa dapat dilihat pada Tabel 1.

Tabel 1. Hasil capaian indikator kecerdasan emosional siswa

\begin{tabular}{ccc}
\hline No & Inisial & Capaian indicator \\
\hline 1. & ZSL & 5 \\
2. & RMR & 5 \\
3. & RMP & 4 \\
4. & SNW & 3 \\
5. & SJRP & 2 \\
6. & RDF & 1 \\
\hline
\end{tabular}

Siswa dengan kecerdasan emosional tinggi adalah siswa yang memiliki kesadaran tinggi untuk mengenali perasaannya dengan melakukan tindakan selajutnya, sama halnya dengan ZSL, RMR, RMP dan SNW mereka mampu mengenali perasaannya saat tidak bisa menyelesaikan tugasnya mereka melakukan tindakan dengan bertanya dengan teman, orang tua dan gurunya. anak yang memiliki kesadaran diri adalah anak yang mengetahui apa yang ia rasakan dan menggunakannya untuk mengambil keputusan diri sendiri memiliki tolok ukur yang realitas untuk mengambil tindakan selanjutnya. Dalam mengelola emosi dengan baik akan membuat kecerdasan emosional tinggi dimana perbaikan toleransi kepada temanteman akan membuat anak menjadi tidak terganggu dengan keadaan lungkungannya, sama halnya dengan ZSl, RMR, RMP mereka memiliki toleransi yang baik pada temannya dimana saat mereka tengah fokus belajar mereka tidak terganggu dengan teman-temannya yang tidak mau belajar dan malah asyik bermain. Hal ini sejalan dengan penelitian sebelumnya yang menyatakan bahwa siswa yang dapat mengenali emosi adalah siwa yang mampu mengembangkan rasa toleransi dengan teman-temannya (Karina et al., 2014).

\section{Pembahasan}

Berdasarkan hasil uraian di atas dapat disimpukan bahwa potret kecerdasan emosional anak selama pembelajaran daring siswa kelas V SD N Jatiroto 02 adalah terdapat 2 siswa dengan prestasi belajar tingi, siswa 1 laki-laki inisial RMR dan 1 perempuan inisial ZSL memiliki kecerdasan emosional sangat tinggi karena mampu mecapai 5 indikator dengan baik. 1 siswa laki-laki dengan prestasi belajar rata-rata berinisial RMP memiliki kecerdasan emosional tinggi dengan mencapai 4 indikator dengan baik. 1 siswa perempuan dengan prestasi belajar rata-rata memiliki kecerdasan emosional rata-rata karena mencapai 3 indikator dengan baik. 1 siswa laki-laki dengan inisial SJRP dengan prestasi belajar rendah memiliki kecerdasan emosional rendah karena mencapai 2 indikator dengan baik dan 1 siswa perempuan dengan prestasi belajar dengan inisial RDF memiliki kecerdasan emosional sangat rendah karena hanya mampu mencapai 1 indikator dengan baik. Menyelaraskan emosi dengan pikiran untuk mempersiapkan tindakan selanjutnya akan meningkatkan kecerdasan emosional, artinya seseorang mampu memanfaatkan emosinya dengan cerdas (Maghfiroh \& Putri Mahanani, 2021; Sa'diyah, 2013). Pendapat ini sesuai dengan apa yang dilakukan oleh ZSI, RMR, RMP mereka mampu memanfaatkan emosi dengan baik dengan mengikuti pembelajaran dengan baik dimana penyelarasan emosi dan pikiran dipusatkan pada tugasnya. Siswa yang memiliki kecerdasan emosional adalah siswa yang mampu membaca emosi dengan baik, hal ini dikarenakan dengan mampu membaca emosii maka akan mampu berempati dan peka terhadap temannya, SJRP, SNW, RMR dan ZSL mampu membaca emosi dan memiliki empati dengan temannya karena saat teman mereka terlihat sedih dan kurang semangat mereka menunjukan kepekaannya dengan bertanya dan menyemangati temannya. Hal ini sejalan dengan penelitian sebelumnya yang menyatakan bahwa keberhasilan siswa dalam mengikuti pembelajaran banyak bergantung pada kecerdasan yang ada pada dirinya (Ardian et al., 2019; Yesi et al., 2016). Siswa dapat 
mencapai prestasi belajar yang baik jika mereka dapat memiliki kecerdasan emosional yang tinggi seperti terdapat salah satu indikator empati atau membaca emosi orang lain, anak yang mampu berempati dan mendengarkan orang lain akan membuat anak lebih cerdas. Lebih baik dalam menyelesaikan pertikaian dapat membuat anak membina hubungan yang baik dengan temannya, ZSL, RMR, RMP, SNW, SJRP, RDF dapat membina hubungan baik dengan temannya hal ini dikarenakan saat mereka bersalah mereka mau meminta maaf untuk menyelesaikan pertikaian, mudah berinteraksi dengan teman dan senang berkunjung kerumah temannya untuk belajar bersama. Hal ini sejalan dengan penelitian sebelumnya yang menyatakan bahwa jika siswa memiliki kecerdasan tinggi, mudah membina interaksi sosial tidak mengalami kesulitan untuk menjalani hubungan dengan teman baru, dapat berkomunikasi secara efektif dengan orang lain sedangkan jika kecerdasan emosional rendah maka rendah pula interaksi sosial siswa (Agustini et al., 2019).

Dengan membina hubungan yang baik dengan orang lain maka seseorang akan lebih dibutuhkan oleh teman sebaya dan lebih baik dalam menyelesaikan masalah yang timbul dalam hubungan. Dengan begitu siswa yang mempunyai kecerdasan emosional tinggi akan mampu melaksanakan proses pembelajaran dengan baik dan maksimal sehingga membuat siswa memiliki prestasi belajar yang baik. Hasil penelitian ini di dukung oleh penelitian terdahulu yang menyatakan bahwa jika siswa memiliki kecerdasan emosional yang tinggi maka besar kemungkinannya akan menentukan keberhasilan belajar siswa (Adnyana et al., 2017; Nurhayati et al., 2021). Tingkat kecerdasan emosional siswa yang tinggi jika memiliki sikap mau mengerti keadaan orang lain dan memiliki empati atau kepekaan terhadap orang lain (Ayu \& Dwi., 2019; Munirah \& Ahmad Putri, 2018; Yaya Setiadi, 2018). Sehingga diharapkan selama pembelajran daring dilaksanakan peserta didik mampu mengelola emosinya dengan melakukan kegiatankegiatan yang positif sehingga kecerdasan emosionalanya terjaga yang akan berdampak terhadap minat serta hasil belajarnya.

\section{SIMPULAN}

Kecerdasan emosional anak saat pembelajaran daring siswa SD $\mathrm{N}$ Jatiroto 02 pelaksanaan pembelajaran daring dilakukan menggunakan media WhatsAap sebagai sarana untuk guru memberikan materi pembelajaran dan tugas-tugas yang harus dikerjakan siswa, begitu pula jika siswa telah menyelesaikan tugasnya mereka mengirimkan hasil pekerjaannya melalui media online WhatsAap.. Tingkat kecerdasan emosional siswa saat pembelajaran daring yakni terdapat 2 siswa dengan kecerdasan emosional sangat tinggi, 1 siswa dengan kecerdasan emosional tinggi, 1 siswa dengan kecerdasan emosional sedang, 1 siswa dengan kecerdasan emosional rendah dan 1 siswa dengan kecerdasan emosional sangat rendah.

\section{DAFTAR RUJUKAN}

Adnyana, I. W. J., Suma, K., \& Suswandi, I. (2017). Kontribusi Motivasi Belajar, Kecerdasan Emosional, Dan Kecerdasan Intelektual Terhadap Prestasi Belajar Fisika. Jurnal Pendidikan Fisika Undiksha, 7(2). https://doi.org/10.23887/jjpf.v7i2.16788.

Agustini, N. K., Sujana, I. W., \& Putra, I. K. A. (2019). Korelasi Antara Kecerdasan Emosional dengan Interaksi Sosial Siswa Kelas V SD Gugus VI Pangeran Diponegoro Denpasar Barat. Jurnal Pedagogi Dan Pembelajaran, 2(1). https://doi.org/10.23887/jp2.v2i1.17620.

Akimas, H. N. (2016). Pengaruh Kecerdasan Intelektual (IQ), Kecerdasan Emosional (EQ), Kecerdasan Spiritual (SQ) Terhadap Kinerja Pegawai Inspektorat Provinsi Kalimantan Selatan. Jurnal Wawasan Manajemen, 4(3), 259-271. https://doi.org/10.20527/jwm.v4i3.99.

Anggriani, A., Sarwi, S., \& Masturi, M. (2020). The Effectiveness of Guided Discovery in Distance Learning to Improve Scientific Literacy Competencies of Primary School Students. Journal of Primary Education, 9(5), 454-462. https://doi.org/10.15294/jpe.v9i4.42600.

Anugrahana, A. (2020). Hambatan, Solusi dan Harapan : Pembelajaran Daring Selama Masa Pandemi Covid-19 Oleh Guru Sekolah Dasar. Scholaria: Jurnal Pendidikan Dan Kebudayaan, 10(3), 282-289. https://doi.org/10.24246/j.js.2020.v10.i3.p282-289.

Ardian, A., Purwanto, S., \& Alfarisi, D. S. (2019). Hubungan prestasi belajar siswa kelas khusus olahraga dengan kecerdasan emosional. Jurnal Keolahragaan, 7(2), 126-134. https://doi.org/10.21831/jk.v7i2.28103.

Arieska, Syafri, \& Zubaedi, Z. (2018). Pengembangan Kecerdasan Emosional (Emotional Quotient) Daniel Goleman Pada Anak Usia Dini Dalam Tinjauan Pendidikan Islam. Al Fitrah: Journal Of Early Childhood Islamic Education, 1(2). https://doi.org/10.29300/alfitrah.v1i2.1337.

Astuti, R., Sugiharto, B., \& Kurniawan, A. (2019). Pengaruh Locus of Control, Ethical Sensitivity, 
Kecerdasan Intelektual, Kecerdasan Emosional, Kecerdasan Spiritual dan Tingkat Pendidikan Terhadap Perilaku Etis. Jurnal Aset (Akutansi Riset), 11(2). https://doi.org/10.17509/jaset.v11i2.19921.

Ayu, S., \& Dwi., M. F. (2019). Kecerdasan Emosional Peserta Didik Di Sd Takhassus Alquran Kalibeber Wonosobo. Jurnal Abdau., 2(1), 101-114.

Binali, T., Tsai, C.-C., \& Chang, H.-Y. (2021). University students' profiles of online learning and their relation to online metacognitive regulation and internet-specific epistemic justification. Computers \& Education, 175. https://doi.org//10.1016/j.compedu.2021.104315.

Costa, M. G. da, Pinto, L. H., Martins, H., \& Vieira, D. A. (2021). Developing psychological capital and emotional intelligence in higher education: A field experiment with economics and management students. The International Journal of Management Education, 19(3), 100516. https://doi.org/10.1016/j.ijme.2021.100516.

Dharmawan, N. A. S. (2013). Pengaruh Kecerdasan Intelektual, Kecerdasan Emosional, Dan Kecerdasan Spiritual Pada Profesionalisme Kerja Auditor. Jurnal Ilmiah Akutansi Dan Humanika, 3(2). https://doi.org/10.23887/jinah.v2i2.1677.

Fauzia, F., Virantika, A., \& Firmansyah, G. (2021). Langkah-langkah Strategis Pemenuhan Kebutuhan SDM Talenta Digital di Lingkungan Pemerintahan Indonesia. 39-46.

Fauziah. (2015). Hubungan Kecerdasan Emosional Dengan Prestasi Belajar Mahasiswa Semester Ii Bimbingan Konseling UIN Ar-Raniry. Jurnal Edukasi, 1(1). https://doi.org/10.22373/je.v1i1.320.

Goleman, D. (2015). Emotional Intelegence. Gramedia Pustaka.

Gunarsih, F. D. (2016). Hubungan Interaksi Sosial, Konsep Diri, Dan Kecerdasan Emosional Terhadap Prestasi Belajar Matematika Siswa Kelas VIII SMP Negeri DI Kecamatan Pituruh. EKUIVALEN, 20(2), 211-216. https://doi.org/10.37729/ekuivalen.v20i3.2901.

Hwang, G. J., Wang, S. Y., \& Lai, C. L. (2020). Effects of a social regulation-based online learning framework on students' learning achievements and behaviors in mathematics. Computers and Education, 160, 104031. https://doi.org/10.1016/j.compedu.2020.104031.

Karina, N. K. D., Sadia, I. W., \& Suastra, I. W. (2014). Pengaruh Model Pembelajaran Berbasis Proyek Terhadap Kemampuan Pemecahan Masalah Dan Kecerdasan Emosional Siswa SMP. Jurnal Pendidikan Dan Pembelajaran IPA Indonesia, 4(1).

Kencanawati, S. A. M. M., Sariyasa, S., \& Hartawan, I. G. N. Y. (2020). Pengaruh penerapan model pembelajaran SAVI (Somatic, Auditory, Visual, Intellectual) terhadap kemampuan berpikir kreatif matematis. Pythagoras: Jurnal Pendidikan Matematika, 15(1), 13-23. https://doi.org/10.21831/pg.v15i1.33006.

Kkese, E. (2020). McGurk effect and audiovisual speech perception in students with learning disabilities exposed to online teaching during the COVID-19 pandemic. Medical Hypotheses, 144(July), 110233. https://doi.org/10.1016/j.mehy.2020.110233.

Lage-Cala, S., Folgueras-Díaza, M. B., Alonso-Hidalgoa, M., García-Menéndezb, D., \& Fernández-Garcíab, F. J. (2020). Investigation of the effectiveness of online learning tools for energy performance certificates preparation. Energy Reports, 6, 609-614. https://doi.org/10.1016/j.egyr.2019.09.034.

Lapitan, L. D., Tiangco, C. E., Sumalinog, D. A. G., Sabarillo, N. S., \& Diaz, J. M. (2021). An effective blended online teaching and learning strategy during the COVID-19 pandemic. Education for Chemical Engineers, 35(May 2020), 116-131. https://doi.org/10.1016/j.ece.2021.01.012.

Liu, Q., Huang, J., \& Zhou, Z. (2020). Self-expansion via smartphone and smartphone addiction tendency among adolescents: A moderated mediation model. Children and Youth Services Review, 119(June), 105590. https://doi.org/10.1016/j.childyouth.2020.105590.

Maghfiroh, W., \& Putri Mahanani, N. (2021). Pengaruh Kecerdasan Emosional terhadap Prestasi Belajar Siswa Kelas IV SD Selama Pembelajaran Daring. Jurnal Pembelajaran, Bimbingan, Dan Pengelolaan Pendidikan, 1(7), 552-562. https://doi.org/10.17977/um065v1i72021p552-562.

Maison, M., Kurniawan, D. A., \& Anggraini, L. (2021). Perception, Attitude, and Student Awareness in Working on Online Tasks During the Covid-19 Pandemic. Jurnal Pendidikan Sains Indonesia, 9(1), 108-118. https://doi.org/10.24815/jpsi.v9i1.18039.

Maqableh, M., \& Alia, M. (2021). Evaluation online learning of undergraduate students under lockdown amidst COVID-19 Pandemic: The online learning experience and students' satisfaction. Children and Youth Services Review, 128(1). https://doi.org/10.1016/j.childyouth.2021.106160.

Mirnawati, M., \& Basri, M. (2018). Pengaruh Kecerdasan Emosional Terhadap Hasil Belajar Matematika Siswa Sekolah Dasar. JRPD (Jurnal Riset Pendidikan Dasar), 1(1). https://doi.org/10.26618/jrpd.v1i1.1240.

Munirah, M., \& Ahmad Putri, S. S. (2018). Pengaruh Kecerdasan Emosional Terhadap Hasil Belajar Matematika Peserta Didik. AULADUNA: Jurnal Pendidikan Dasar Islam, 5(2). 
https://doi.org/10.24252/auladuna.v5i2a2.2018.

Nambiar, D. (2020). The impact of online learning during COVID-19 : students ' and teachers ' perspective. The International Journal of Indian Psychology, 8(2), 783-793. https://doi.org/10.25215/0802.094.

Nurdiansyah, E. (2016). Pengaruh Kecerdasan Spiritual, Kecerdasan Emosional, Dampak Negatif Jejaring Sosial Dan Kemampuan Berpikir Divergen Terhadap Hasil Belajar Matematika Siswa. Journal of EST, 2(3), 171-184. https://doi.org/10.26858/est.v2i3.3216.

Nurfitriyanti, M. (2017). Pengaruh Model Pembelajaran Kooperatif Tipe Jigsaw Terhadap Hasil Belajar Matematika ditinjau dari Kecerdasan Emosional. Formatif: Jurnal Ilmiah Pendidikan MIPA, 7(2). https://doi.org/10.30998/formatif.v7i2.2229.

Nurhayati, L., Maula, L. H., \& Nurasiah, I. (2021). Kecerdasan Emosional dan Kemampuan Berpikir Kritis pada Materi Bangun Datar di Kelas Tinggi Sekolah Dasar. Mimbar Ilmu, 26(2). https://doi.org/10.23887/mi.v26i2.36919.

Prafitriani, S., Umanailo, M. C. B., Indrayani, N., Lisaholit, S., \& Chamidah, D. (2019). Pengaruh Kecerdasan Emosional terhadap Hasil Belajar Matematika Siswa Kelas VII SMP Negeri 9 Buru. Jurnal Penelitian Pendidikan Matematika, 6(2). https://doi.org/10.36709/jppm.v6i2.9121.

Pratiwi, I. A., Ardianti, S. D., \& Kanzunnudin, M. (2018). Peningkatan Kemampuan Kerjasama Melalui Model Project Based Learning (PjBL) Berbantuan Metode Edutainment Pada Mata Pelajaran Ilmu Pengetahuan Sosial. Refleksi Edukatika: Jurnal Ilmiah Kependidikan, 8(2). https://doi.org/10.24176/re.v8i2.2357.

Priadi, A. (2018). Pengaruh Kecerdasan Intelektual, Kecerdasan Emosional Dan Kecerdasan Spiritual Terhadap Kinerja Guru(Studi Kasus SMA Negeri 6 DAN SMA Negeri 8 Kota Tangerang Selatan). Jurnal Semarak, 1(3), 62-77. https://doi.org/10.32493/smk.v1i3.2260.

Putri, R. S., \& Purwanto, D. (2020). (2020). Impact of the COVID-19 pandemic on online home learning: An explorative study of primary schools in Indonesia. International ,. Journal of Advanced Science and Technology, 29(5), 4809-4818.

Putri, Y. S. (2016). Pengaruh Kecerdasan Intelektual, Kecerdasan Emosional, Dan Lingkungan Kerja Terhadap Kinerja Karyawan PT. PLN Persero Area Klaten. Jurnal Studi Manajemen Organisasi. https://doi.org/10.14710/jsmo.v13i1.13416.

Putria, H., Maula, L. H., \& Uswatun. D. A. (2020). Analisis Proses Pembelajaran Dalam Jaringan (DARING) Masa Pandemi COVID-19 pada Guru Sekolah Dasar. Jurnal Basicedu, 4(4), 861-872. https://doi.org/10.31004/basicedu.v4i4.460.

Rachmiati, I. (2016). Kecerdasan Emosional Dan Konsep Diri Dengan Hasil Belajar IPS. Jurnal Pendidikan Dasar, 7(2), 225-236. https://doi.org/10.21009/JPD.072.04.

Rahmawati, M., \& Latifah, M. (2020). Penggunaan Gawai, Interaksi Ibu-Anak, Dan Perkembangan SosialEmosional Anak Prasekolah. Jurnal Ilmu Kel. Dan Konseling, 13(1), 75-86. https://doi.org/10.24156/jikk.2020.13.1.75.

Rambe, Hasanah, \& Chairunnisa. (2018). Hubungan Kecerdasan Emosional Dengan Hasil Belajar Biologi Siswa Kelas X MIA MAN 3 Medan T.P. 2017/2018. Jurnal Pelita Pendidikan, 6(2). https://doi.org/10.24114/jpp.v6i2.10145.

Ratnadi, N. W. R. W. N. M. D. (2017). Pengaruh Kecerdasan Emosional, Kecerdasan Intelektual, Dan Perilaku Belajar Pada Tingkat Pemahaman Akuntansi. E-Jurnal Akuntansi, 1(1). https://doi.org/10.24843/EJA.2017.v20.i02.p10.

Risma, D. (2012). Pengaruh Kecerdasan Emosional Terhadap Kinerja Karyawan : Penelitian Eksperimen. Jurnal Educhild Pendidikan Dan Sosial, 1(1). https://doi.org/10.33578/jpsbe.v1i1.1628.

Sa'diyah, R. (2013). Urgensi Kecerdasan Emosional Bagi Anak Usia Dini. Cakrawala Dini: Jurnal Pendidikan Anak Usia Dini, 4(1). https://doi.org/10.17509/cd.v4i1.10375.

Saha, A., Dutta, A., \& Sifat, R. I. (2021). The mental impact of digital divide due to COVID-19 pandemic induced emergency online learning at undergraduate level: Evidence from undergraduate students from Dhaka City. Journal of Affective Disorders, 294(June), 170-179. https://doi.org/10.1016/j.jad.2021.07.045.

Said, A. N., \& Rahmawati, D. (2018). Pengaruh Kecerdasan Intelektual, Kecerdasan Emosional Dan Kecerdasan Spiritual Terhadap Sikap Etis Mahasiswa Akuntansi (Studi Empiris Pada Mahasiswa Prodi Akuntansi Universitas Negeri Yogyakarta). Nominal, Barometer Riset Akuntansi Dan Manajemen, 7(1). https://doi.org/10.21831/nominal.v7i1.19357.

Sairo, A. I., Meta, M., \& Berkhmas., M. Y. (2019). Kecerdasan Emosional Peserta Didik Sekolah Dasar. Profesi Pendidikan Dasar, 6(1), 41-50. https://doi.org/10.23917/ppd.v1i1.7946.

Samaha, M., \& Hawi, N. S. (2016). Computers in Human Behavior Relationships among smartphone addiction, stress, academic performance, and satisfaction with life. Computers in Human 
Behavior, 57, 321-325. https://doi.org/10.1016/j.chb.2015.12.045.

Saputra, N., Hikmah, N., Yustitia, V., Saputra, M., Wahab, A., \& Junaedi, J. (2021). Implementation of Online Learning Using Online Media, During the Covid 19 Pandemic. Budapest International Research and Critics Institute (BIRCI-Journal): Humanities and Social Sciences, 4(2), 1802-1808. https://doi.org/10.33258/birci.v4i2.1857.

Satriyono, G., \& Vitasmoro, Pa. (2018). Pengaruh Kecerdasan Emosional Terhadap Kinerja Guru Di SMP Negeri 4 Kediri. Jurnal Ekonomi Universitas Kediri, 3(1), 31-45. https://doi.org/10.30737/ekonika.v3i1.104.

Selvaraj, A., Radhin, V., KA, N., Benson, N., \& Mathew, A. J. (2021). Effect of pandemic based online education on teaching and learning system. International Journal of Educational Development, 85(May), 102444. https://doi.org/10.1016/j.ijedudev.2021.102444.

Setiadi, Y. (2018). Hubungan Konsep Diri, Kecerdasan Emosional, dan Kecemasan Belajar dengan Prestasi Belajar Mahasiswa. JNPM (Jurnal Nasional Pendidikan Matematika), 2(1). https://doi.org/10.33603/jnpm.v2i1.1066.

Setyawan, A. A., \& Simbolon, D. (2018). Pengaruh Kecerdasan Emosional Terhadap Hasil Belajar Matematika Siswa Sekolah Dasar. JPPM (Jurnal Penelitian Dan Pembelajaran Matematika), 1(1). https://doi.org/10.30870/jppm.v11i1.2980.

Sugiyono. (2016). Metode Penelitian Kualitatif, Kuantitatif, dan R\&D. Alfabeta.

Suhendro, E. (2020). Strategi Pembelajaran Pendidikan Anak Usia Dini di Masa Pandemi Covid-19. Golden Age: Jurnal Ilmiah Tumbuh Kembang Anak Usia Dini, 5(3), 133-140. https://doi.org/10.14421/jga.2020.53-05.

Supriyanto, D. H. (2021). Analisis Pengaruh Kecerdasan Emosional Terhadap Proses Berfikir Siswa Kelas IV dalam Memecahkan Masalah Matematika. Jurnal Pendidikan Modern, 6(2). https://doi.org/10.37471/jpm.v6i2.208.

Suryana. (2020). Permasalahan Mutu Pendidikan Dalam Perspektif Pembangunan Indonesia. Jurnal Edukasi, 14(1). https://doi.org/10.15294/edukasi.v14i1.971.

Susilo, A., Rumende, C. M., Pitoyo, C. W., Santoso, W. D., Yulianti, M., Herikurniawan, H., Sinto, R., Singh, G., Nainggolan, L., Nelwan, E. J., Chen, L. K., Widhani, A., Wijaya, E., Wicaksana, B., Maksum, M., Annisa, F., Jasirwan, C. O. M., \& Yunihastuti, E. (2020). Coronavirus Disease 2019: Tinjauan Literatur Terkini. Jurnal Penyakit Dalam Indonesia, 7(1), 45. https://doi.org/10.7454/jpdi.v7i1.415.

Wulandari, N. P. R., Dantes, N., \& Antara, P. A. (2020). Pendekatan Pendidikan Matematika Realistik Berbasis Open Ended Terhadap Kemampuan Pemecahan Masalah Matematika Siswa. Jurnal Ilmiah Sekolah Dasar Universitas Pendidikan Ganesha, 4(2), 153-164. https://doi.org/10.23887/jisd.v4i2.25103.

Yaya Setiadi. (2018). Hubungan Konsep Diri, Kecerdasan Emosional, dan Kecemasan Belajar dengan Prestasi Belajar Mahasiswa. JNPM (Jurnal Nasional Pendidikan Matematika), 2(1). https://doi.org/10.33603/jnpm.v2i1.1066.

Yesi, I., Riswan, J., \& Ikbal., B. (2016). Pengaruh Kecerdasan Emosional Terhadap Prestasi Belajar Akuntansi Keuangan Siswa Kelas Xi Di Smk Negeri 5 Palembang Tahun Pelajaran 2015/2016. Jurnal Profit, 3(2). https://doi.org/10.36706/jp.v3i2.5565. 